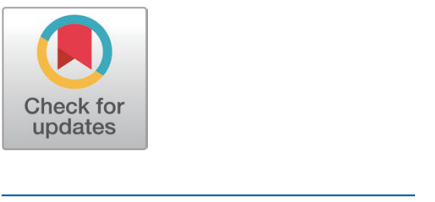

Received: May 20, 2021

Revised: Jul 26, 2021

Accepted: Aug 30, 2021

*Corresponding author

Sun Jin Hur

Department of Animal Science and

Technology, Chung-Ang University,

Anseong 17546, Korea.

Tel: +82-31-670-4673

E-mail: hurs@@cau.ac.kr

Copyright $\odot 2021$ Korean Society of Animal Sciences and Technology.

This is an Open Access article distributed under the terms of the Creative Commons Attribution Non-Commercial License (http:// creativecommons.org/licenses/bync/4.0/) which permits unrestricted non-commercial use, distribution, and reproduction in any medium, provided the original work is properly cited.

ORCID

Da Young Lee

https://orcid.org/0000-0002-3172-0815

Seung Yun Lee

https://orcid.org/0000-0002-8861-6517

Cheorun Jo

https://orcid.org/0000-0003-2109-3798

Yohan Yoon

https://orcid.org/0000-0002-4561-6218

Jong Youn Jeong

https://orcid.org/0000-0001-5284-4510

Sun Jin Hur

https://orcid.org/0000-0001-9386-5852

Competing interests

No potential conflict of interest relevant to this article was reported.

Funding sources

This work was carried out with the support of "Cooperative Research

Program for Agriculture Science

\section{Effect on health from consumption of meat and meat products}

\author{
Da Young Lee ${ }^{1}$, Seung Yun Lee ${ }^{1}$, Cheorun $\mathrm{Jo}^{2}$, Yohan Yoon ${ }^{3}$, \\ Jong Youn Jeong ${ }^{4}$ and Sun Jin Hur ${ }^{1 *}$ \\ ${ }^{1}$ Department of Animal Science and Technology, Chung-Ang University, Anseong 17546, Korea \\ ${ }^{2}$ Department of Agricultural Biotechnology, Research Institute of Agriculture and Life Science, Seoul \\ National University, Seoul 08826, Korea \\ ${ }^{3}$ Department of Food and Nutrition, Sookmyung Women's University, Seoul 04310, Korea \\ ${ }^{4}$ School of Food Biotechnology and Nutrition, Kyungsung University, Busan 48434, Korea
}

\begin{abstract}
The aim of this study was to investigate the effects of dietary sodium nitrite and meat on human health. Sodium nitrite in processed meat is known to be one of the main precursors of carcinogens, such as $\mathrm{N}$-nitroso compounds. However, we previously found that processed meat is not the primary source of sodium nitrite; nitrate or the conversion of nitrate in vegetables are contribute to generate more than $70 \%$ Sodium nitrite or nitrate containing compounds in body. Although the heavy consumption of meat is likely to cause various diseases, meat intake is not the only cause of colorectal cancer. Our review indicates that sodium nitrite derived from foods and endogenous nitric oxide may exhibit positive effects on human health, such as preventing cardiovascular disease or improving reproductive function. Therefore, further epidemiological studies considering various factors, such as cigarette consumption, alcohol consumption, stress index, salt intake, and genetic factors, are required to reliably elucidate the effects of dietary sodium nitrite and meat on the incidence of diseases, such as colorectal cancer.
\end{abstract}

Keywords: Dietary sodium nitrite, Meat products, Colorectal cancer, Human health

\section{INTRODUCTION}

In October 2015, the International Agency for Research on Cancer (IARC), which is a part of the World Health Organization (WHO), reported a risk of carcinogenicity with the consumption of red and processed meat. After reviewing relevant scientific literature providing sufficient evidence that processed meat consumption causes colorectal cancer in humans, the IARC working groups classified the consumption of red meat as "probably carcinogenic" (Group 2A) and that of processed meat as "carcinogenic" (Group 1) [1]. The incidence of colorectal cancer is known to be related to the content of meat heme iron, $\mathrm{N}$-nitroso compounds, heterocyclic amines, or polycyclic aromatic hydrocarbons because these substances can cause genotoxicity and metabolic disorders of the colon mucosa. Numerous previous studies have suggested that the incidence of colorectal cancer due to the consumption of processed meat is closely related to the addition of sodium nitrite during the processing of meat [2-4]. Sodium nitrite reacts with amines, amides, and other nitrosation precursors in the gastrointestinal tract to form $\mathrm{N}$-nitroso compounds, which are potent carcinogens [5]. However, there 
and Technology Development (Project No. PJ016201)" Rural Development

Administration, Korea.

Acknowledgements

Not applicable.

Availability of data and material Upon reasonable request, the datasets of this study can be available from the corresponding author.

\section{Authors' contributions \\ Investigation: Lee DY, Lee SY, Hur SJ. \\ Writing - original draft: Lee DY, Lee SY, Hur SJ. \\ Writing - review \& editing: Jo C, Yoon Y, Jeong JY, Hur SJ.}

Ethics approval and consent to participate This article does not require IRB/IACUC approval because there are no human and animal participants. is increasing scientific controversy regarding the effect of nitrite/nitrate and related nitrogen species, such as nitric oxides (NO), on human health [6]. The European Food Safety Authority (EFSA) [7] reported that the most important dietary sources of nitrate are vegetables and fruits, contributing $50 \%$ to $75 \%$ of the overall dietary intake in both the United Kingdom and France. Moreover, the relationship between meat consumption and colorectal cancer incidence remains controversial, as it is contradicted by additional statistical data [8-10]. Our previous study [10] also found that the incidence of colorectal cancer may be related to causative factors other than meat consumption, such as ethnicity, dietary habits, alcohol consumption, smoking, stress, exercise, medical checkup frequency, or environmental pollution. Therefore, the purpose of this review was to provide information regarding the effects of dietary sodium nitrate/nitrite on human health and the main metabolic action of sodium nitrate/nitrite in the body.

\section{HISTORY OF THE USE OF NITRITES AND RELATED HEALTH CONCERNS}

The main roles of nitrite in meat products include color fixation, flavor enhancement, antioxidant activity, and antimicrobial (Clostridium botulinum) preservation [11-17]. Nitrite can break down into NO through several stages, which is then reliably combined with the heme pigment (myoglobin) in the meat, allowing the maintenance of a stable pink color in cooked meat products; the most important factors affecting meat color are the content and chemical state of myoglobin [17]. However, the cause of the improvement in the aroma and taste of meat products by nitrites are still unclear [18]. In the early 1970s, controversy began over the safety of consumption of meat products after reports were made that the nitrite-added meat products reacted with amines to form carcinogenic nitrosamines [17]. Despite these controversies, nitrite is still widely used in meat products as it is the only additive that can inhibit the growth of C. botulinum [19]. Moreover, in 2001, the National Toxicology Program in the United States announced that the animal testing of rodents over several years did not show any evidence regarding the carcinogenicity of nitrites [20]. In fact, nitrite itself is not a carcinogen, but it results in the production of nitrosamine (a carcinogen) when it reacts with amines produced by the decomposition of proteins or when a product containing nitrite, such as bacon, is heated at temperatures above $182^{\circ} \mathrm{C}\left(360^{\circ} \mathrm{F}\right)$ for more than $12 \mathrm{~min}$ and it exhibit a problem [17,21]. Despite several studies aimed at finding substitutes for nitrites, to date, no substance has been found that exhibits all the properties of nitrites [15]. However, in some food industries, a process called "natural curing" has been applied to some meat products [14] and is currently being used to obtain "synthetic nitrite-free" meat products [17,22]. This technique has been applied to replace synthetic nitrites traditionally used in the curing process, and utilizes the high levels of nitrates in vegetables. In the process of making processed meat, vegetable extracts containing sufficient nitrates and fermention bacteria are added together. A portion of the nitrate is reduced to nitrite through bacteria and which is effective enough to replace the synthetic nitrite required for manufacturing processed meat during curing proceeds $[23,24]$. The alternative method of nitrite for meat products is a newly attempted method and is not fundamentally a method of manufacturing meat products in which nitrates are excluded, so there is some controversy over its use and safety [17]. Nevertheless, Europe and the United States have also adopted and used this method of vegetable powder replacement in commercial products, and continued research has strengthened safety and quality stability $[18,25]$. In addition, since the residual amount and addition amount of nitrite ions to processed meat tends to decrease gradually compared to the past, it can be considerd that the risk of ingestion of processed meat due to nitrite is further reduced [17]. According to Keeton et al. [19], residual nitrite ion amounts among meat 
products sold in major cities in the U.S. were found to be $7 \mathrm{ppm}$ in hot dogs, bacon and ham products, which is decreased about $80 \%$ compared to 1980s. Therefore, it can be considerd that the intake of nitrite through meat products will be extremely small.

In fact, the intake of nitrite from processed meat products is highly low level, and this result can also be confirmed through a study on nitrites taken from domestic meat processing and salted fish products. According to a survey of nitrite taken from domestic meat processing and salted fish products, daily estimated intake of nitrite in Koreans was $0.87 \mu \mathrm{g} / \mathrm{kg}$ [26], which is only $1.25 \%$ of the daily permissible amounts of $70 \mu \mathrm{g} / \mathrm{kg}$ weight of meat products by The Joint FAO/WHO Expert Committee on Food Additives (JECFA) [17,27]. A study by Choi et al. [28] examined the average intake of nitrite in seven kinds of nitrite-containing foods (hams, bacon, sausages, fish cakes, salted fish, beef jerky, and processed meats) in Korea, and found that when all seven kinds of food are ingested, they consume about $0.7 \mu \mathrm{g} / \mathrm{kg}$ body weight on a daily basis. The estimated daily intake of nitrite from processed meat in Belgium is about $3 \mathrm{ug} / \mathrm{kg}$ [29], which is higher than the estimated intake in Korea, but is significantly lower than the allowable daily allowance standard. These finding indicates that, contrary to common concerns in Korea, nitrite intake through processed foods containing nitrite is low, meaning that nitrite intake from processed foods poses very little harm to human health.

\section{INTAKE OF NITRITES AND THE CONCENTRATION OF RESIDUAL SODIUM NITRITES IN PROCESSED MEAT}

In 2015, the Rural Development Administration (RDA) of Korea measured the residual amounts of nitrites added to emulsified sausages [30]. In the manufacture of emulsion-type sausages ( $\mathrm{pH}$ 5.8-6.2; sodium chloride $[\mathrm{NaCl}] 1 \%$ ), nitrite was added at 30,60, 90, and $120 \mathrm{ppm}$ and heated at $75^{\circ} \mathrm{C}$ for $40 \mathrm{~min}$ to measure the amount of residual nitrites. The results showed that the amounts of residual nitrates in emulsified sausages were 13.6, 27, 41.8, and $50.6 \mathrm{ppm}$ after nitrite addition at 30, 60, 90, and $120 \mathrm{ppm}$, respectively (Fig. 1). These results indicate that approximately $45 \%$ of the added nitrites remained unchanged even after heat treatment.

Based on these results, the residual amount of nitrite in an emulsion-type sausage was calculated, and it was estimated that approximately $0.451 \mathrm{ppm}$ would remain in the final product if $1 \mathrm{ppm}$ of nitrite was initially added during the manufacture of these emulsion-type sausages. In addition, the residual nitrite content in the emulsion-type sausages with added nitrites continued to decrease as the storage period increased [30]. Therefore, the nitrite content is continuously reduced during the handling and storage of meat products and during the meat processing stages, such as heating processing.

The standards for nitrite and nitrate addition standards for meat products are different by country, whereas the residual amount in meat products is indicated as a standard in Korea, the United States and Europe. In addition, the International Food Standards (CODEX, Codex Alimentarius Commission) indicates food addition standards as the added amount. According to CODEX, a joint food standard of FAO/WHO, when nitrites or nitrates (or a combination of both) in processed meat are used, sodium nitrite should not be added in the final product to more than $200 \mathrm{mg} / \mathrm{kg}$ [31,32]. According to JECFA [27], the acceptable daily intake of synthetic nitrite is $0-0.07 \mathrm{mg} / \mathrm{kg}$ body weight $(\mathrm{bw}) /$ day. The residual amount of synthetic nitrite in the meat product decreases during the storage period after the heating of products. In the United States, it is regulated to contain less than $200 \mathrm{ppm}$ of sodium nitrite and less than $500 \mathrm{ppm}$ of sodium nitrate in finished meat products [31]. In Europe, nitrite must be mixed and distributed in the form of nitrite-pickling salt (NPS) and nitrite residues are limited to $100 \mathrm{mg} / \mathrm{kg}$ in sterilized meat products and $150 \mathrm{mg} /$ 


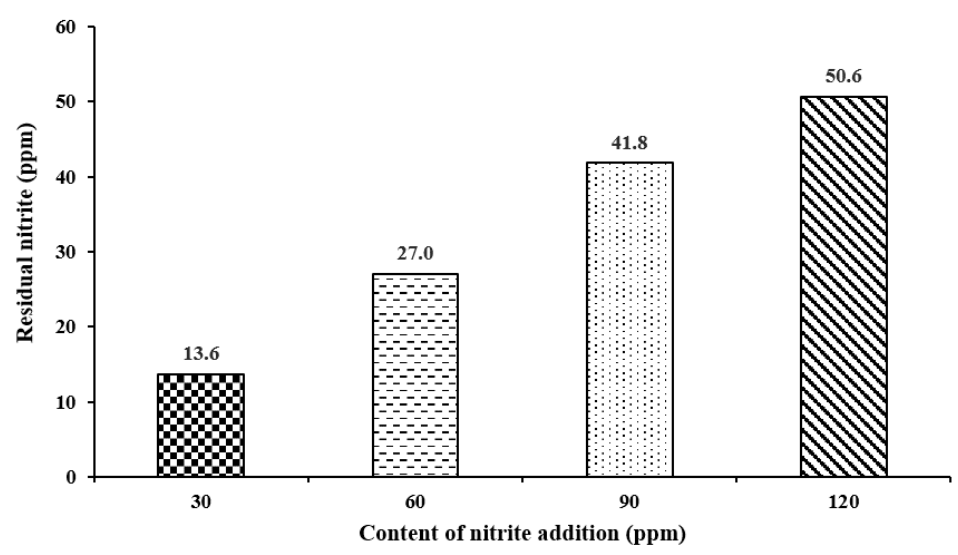

Fig. 1. The content of residual nitrites after nitrite addition. Adapted and modified from Oh et al. with permission of Rural Development Administration (RDA) [30].

$\mathrm{kg}$ in other meat products [33]. Also, nitrates are $150 \mathrm{mg} / \mathrm{kg}$ in common meat products, but some recipes limit it to $250-300 \mathrm{mg} / \mathrm{kg}$ in ham and bacon [33]. However, in many Asian countries, including Korea, the maximum residue limit (MRL) of nitrites in processed meat products is strictly regulated to less than $70 \mathrm{ppm}$ [34]. The nitrite content of meat products measured by the Korea Food Safety Research Institute [35] was $16.6 \mathrm{ppm}$ in ham, $14.6 \mathrm{ppm}$ in sausages, and 15.8 ppm in bacon. In addition, daily intake of these processed meat products was found to be $2.9 \mathrm{~g}, 1.2$ $\mathrm{g}$, and $0.1 \mathrm{~g}$, respectively. Fig. 2 shows that the nitrite intake via meat products is very low, with only $48.1 \mu \mathrm{g}$ for ham, $17.5 \mu \mathrm{g}$ for sausages, and $1.5 \mu \mathrm{g}$ for bacon. This standard is much lower than the standard for the amount of residual nitrates in processed meat products in foreign countries (e.g., United States: nitrites $\leq 200$ ppm, nitrates $\leq 500$ ppm; European Union [EU]: nitrites $\leq 150 \mathrm{mg} / \mathrm{kg}$, nitrates $\leq 150 \mathrm{mg} / \mathrm{kg}$ ), which is considered safe. The amount of residual nitrates of these products in Korea is markedly lower than the standard, which is why these products are considered to safe for consumption.

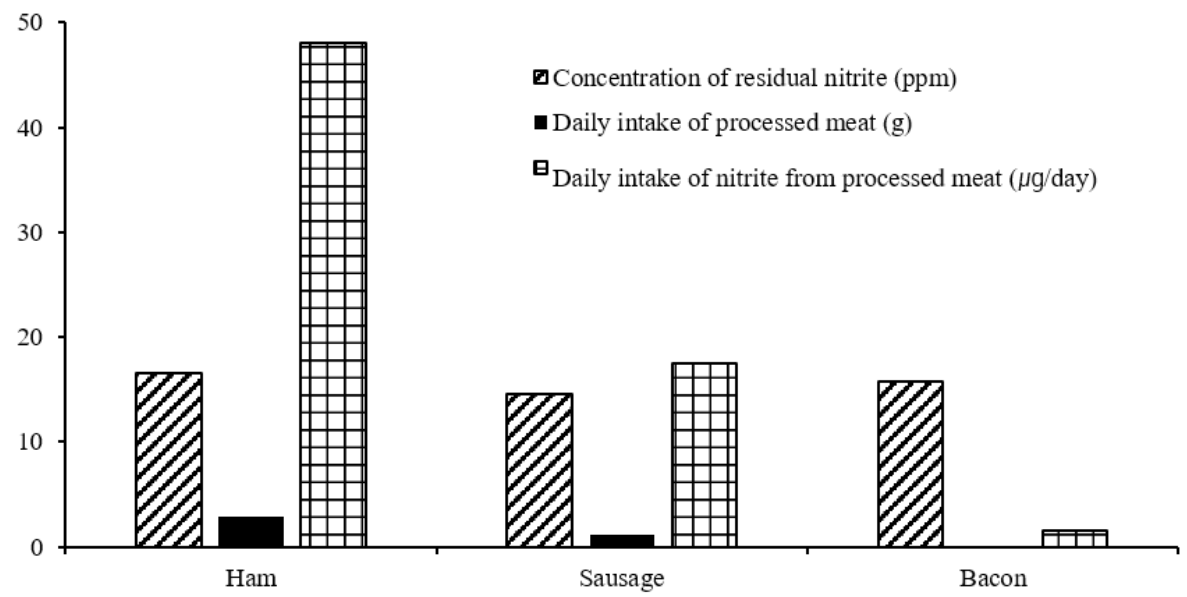

Fig. 2. Residual nitrite concentration and daily intake of processed meats. Adapted and modified from Lee et al. with permission of Korea Food Safety Research Institute (KFSRI) [35]. 
Ham et al. [36] investigated the nitrite content of 450 Korean meat products. The results showed that, on an average, ham products contained $11 \mathrm{ppm}(0-55 \mathrm{ppm})$, sausages contained $14 \mathrm{ppm}$ (0-45 ppm), bacon contained $11 \mathrm{ppm}(0-89 \mathrm{ppm})$, and ground meat products contained $5 \mathrm{ppm}$ (0-40 ppm) of nitrites. Samples with more than $10 \mathrm{ppm}$ nitrite content were ham (45.9\%), sausage (62.5\%), bacon (37.5\%), and ground meat products (12.5\%) [30]. Meanwhile, more than $30 \mathrm{ppm}$ nitrite content was observed in 14 cases of ham, 5 cases of sausage, 1 case of bacon, and 1 case of ground meat products, thereby indicating that the use of nitrites in processed meat products is very common. The Korea Health Industry Development Institute investigated the nitrite ion content in ham, bacon, and sausages and found that the average nitrite ion content was at a minimum of 1.2 ppm to a maximum of $9.4 \mathrm{ppm}$ whereas the detection mean nitrite ion content was at a minimum of $1.8 \mathrm{ppm}$ to a maximum of $11.0 \mathrm{ppm}$ [37]. Among the meat products, ham had the highest nitrite ion content.

In addition, Kim et al. [38] evaluated the nitrite ion content of 1,271 processed meat samples in Seoul, Korea for 3 years from 2012 to 2014 and found that the nitrite content varied from negligible amounts to $63 \mathrm{ppm}$ (Fig. 3).

The content of nitrites and nitrates in processed meat products is regulated in Korea and abroad. Table 1 shows that the content of nitrites and nitrates in processed meat products depends on each country. Australian ham and Frankfurt ham had the highest nitrite content, whereas processed meat products in the United States had the lowest nitrite content. However, the nitrite content of meat products in Australia is below the maximum allowable limit of $125 \mathrm{ppm}$ set by the Food Standards Australia and New Zealand. Compared with nitrates, nitrites were found in large amounts in most countries. Notably, Chorizo products in the United States and France contain approximately 112 and 50 times more nitrate than nitrite, respectively (Table 1).

Lee et al. [44] purchased a total of 12 types of meat products, including nine types of processed meat marked for nitrite use and three types of processed meat marked for non-nitrite use at a supermarket in Chuncheon City, Korea and analyzed the nitrite content [44]. The nitrite content in the processed meats was found at a minimum of $0.29 \mathrm{ppm}$ to a maximum of $44.72 \mathrm{ppm}$ (Fig. 4).

Sindelar and Milkowski [25] suggested that if nitrite ions remain at approximately $10 \mathrm{ppm}$ in common cured meat products, negligible concentrations of nitrite ions $(0.05-0.6 \mathrm{ppm}$ per day) will be introduced into the human body when $75 \mathrm{~g}$ of meat products is ingested (Table 2).

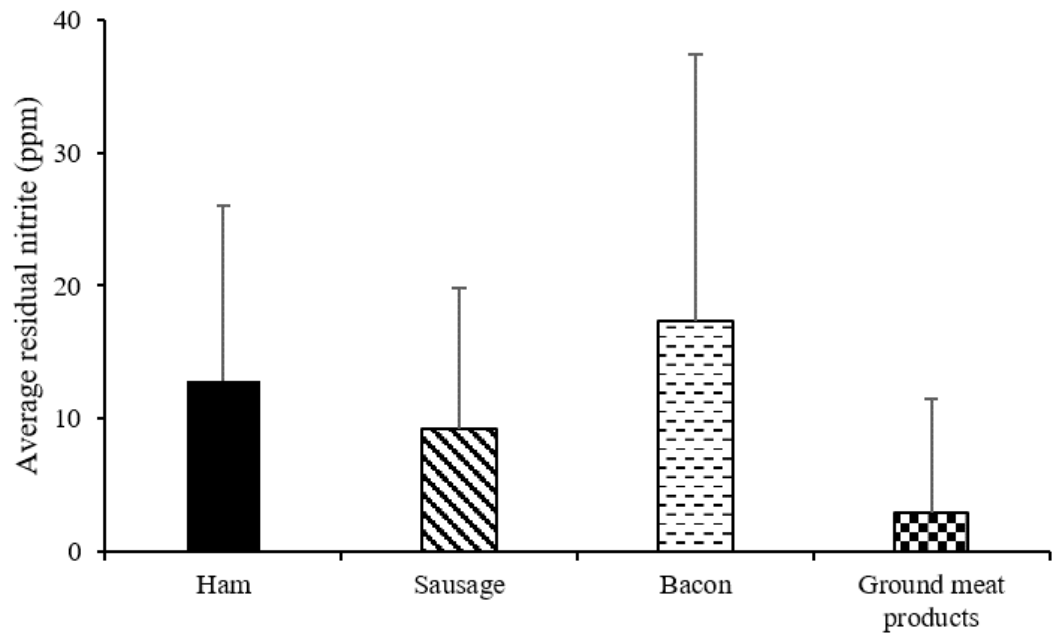

Fig. 3. Residual nitrite concentrations in different types of processed meat in Seoul Korea. Adapted and modified from Kim et al. with permission of Seoul Research Institute of Public Health and Environment [38]. 
Table 1. Content of nitrites and nitrates in processed meat products in the market by country

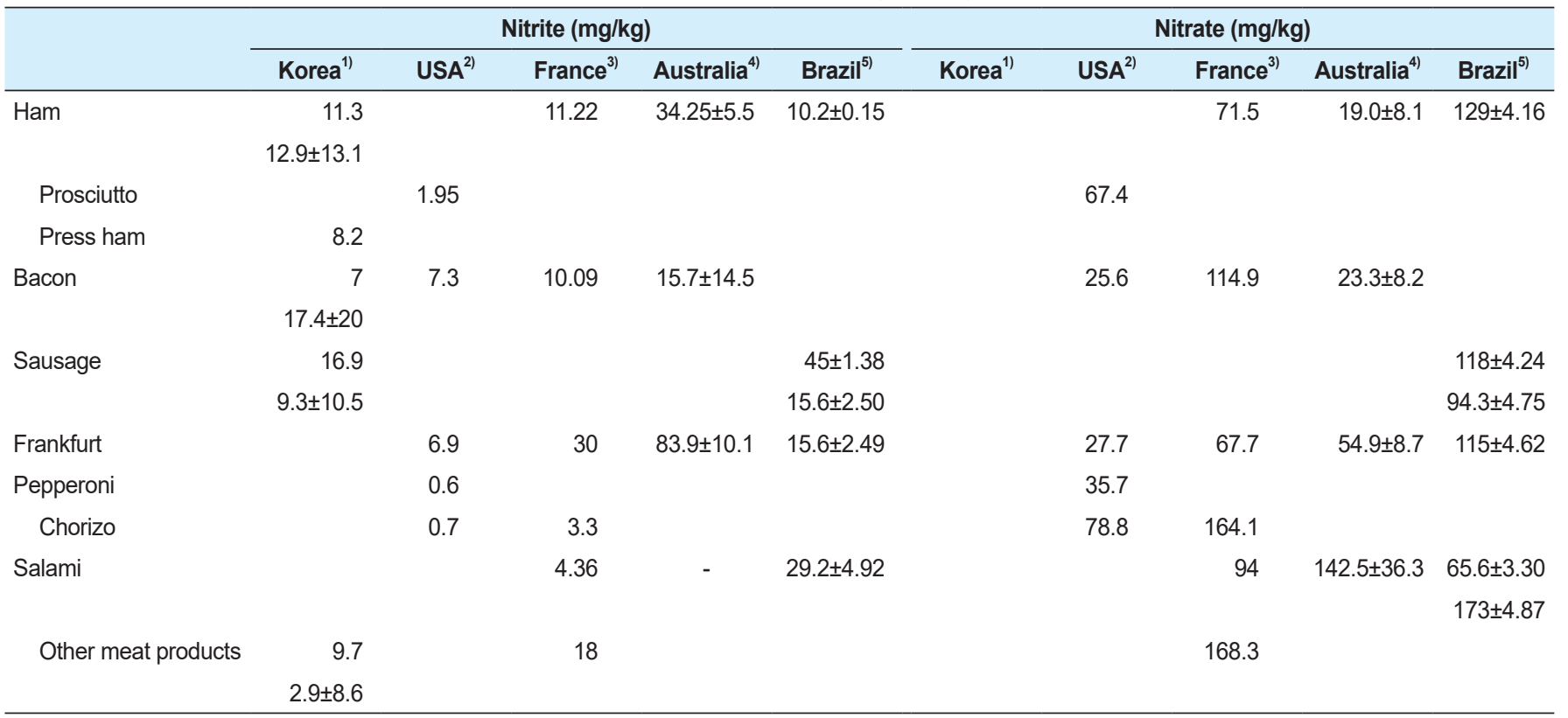

${ }^{1)}$ Adapted from Lee et al. [26]; Adapted from Choi and Suh [39].

${ }^{2)}$ Adapted from Lee [40].

${ }^{3)}$ Adapted from Menard et al. [41].

${ }^{4)}$ Adapted from $\mathrm{Hsu}$ et al. [42].

${ }^{5)}$ Adapted from Della et al. [43].

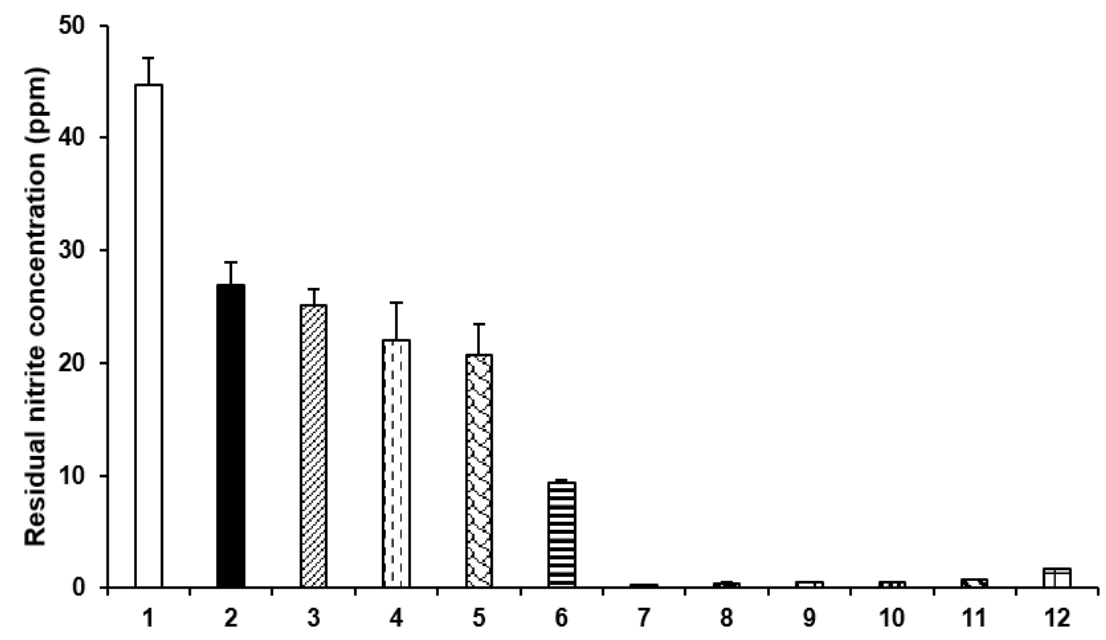

Fig. 4. Residual nitrite concentrations in 12 types of processed meats in the market. Adapted and modified from Lee et al. with permission of Agriculture and Life Sciences Research Institute [44].

Lee et al. [26] analyzed the daily estimated intake of nitrite according to the average consumption of processed foods, such as processed meats in Korea. The daily average estimated intake was $48.6 \mu \mathrm{g} / \mathrm{capita} / \mathrm{day}(0.87 \mu \mathrm{g} / \mathrm{kg}$ weight/day), which was $1.25 \%$ of the acceptable daily intake of $70 \mu \mathrm{g} / \mathrm{kg}$ weight/day, indicating that intake through processed foods containing nitrite was low, contrary to common concerns (Table 3).

In addition, comparing the average nitrite intake in foreign countries (Fig. 5), the daily estimated intake of nitrite in Korea was relatively lower than that in other countries; the daily nitrite intake in 
Table 2. The intake of nitrate and nitrite ion through foods and daily biosynthesis of nitric oxide in $70 \mathrm{~kg}$ adults

\begin{tabular}{|c|c|c|c|}
\hline Intake sources & $\begin{array}{c}\text { Nitrate ions } \\
(\mathrm{mg} / \mathrm{kg} \mathrm{NO} \\
\end{array}$ & $\begin{array}{c}\text { Nitrite ions } \\
\left(\mathrm{mg} / \mathrm{kg} \mathrm{NO}_{2}^{-}\right)\end{array}$ & $\begin{array}{l}\text { Biosynthesis of nitric oxide } \\
\text { (mg/kg NO) }\end{array}$ \\
\hline $75 \mathrm{~g}$ daily intake of cured meat products ${ }^{2)}$ & $1.5-6$ & $0.05-0.6$ & - \\
\hline Saliva ${ }^{4)}$ & $>30-1,000$ & $5.2-8.6$ & - \\
\hline Biosynthesis $^{5)}$ & - & - & 70 \\
\hline
\end{tabular}

${ }^{11}$ Adapted from IARC [45].

${ }^{2)}$ Adapted from Keeton et al. [19].

${ }^{3}$ United States Environmental Protection Agency.

${ }^{4)}$ Adapted from Hord et al. [46].

${ }^{5} 70 \mathrm{~kg}$ based on the daily biosynthesis of $\mathrm{mg} / \mathrm{kg}$ for adults; Adapted from Sindelar and Milkowski with permission of American Meat Science Association [25].

Table 3. Daily estimated intake of nitrites according to the average consumption of processed foods, such as processed meats

\begin{tabular}{|c|c|c|c|c|c|c|}
\hline Foods & $\begin{array}{l}\text { Sample } \\
\text { numbers }\end{array}$ & $\begin{array}{l}\text { Detected sample } \\
\text { number }\end{array}$ & $\begin{array}{l}\text { Concentration } \\
\text { range }(\mu \mathrm{g} / \mathrm{g})\end{array}$ & $\begin{array}{c}\text { Average con- } \\
\text { centration } \\
(\mu \mathrm{g} / \mathrm{g})\end{array}$ & $\begin{array}{l}\text { Average intake } \\
\text { (g/per capital } \\
\text { day) }\end{array}$ & $\begin{array}{l}\text { Average estimat- } \\
\text { ed daily intake } \\
\text { ( } \mu \text { g/capita/day) }\end{array}$ \\
\hline $\begin{array}{l}\text { Processed marine products (Ham, } \\
\text { sausage) }\end{array}$ & 14 & 9 & $0^{1)}-26.5$ & 2.35 & 0.02 & 0.05 \\
\hline Bacon & 6 & 5 & $0-21.17$ & 4.66 & 0.18 & 0.84 \\
\hline Ham & 69 & 66 & $0-42.10$ & 9.28 & 2.96 & 27.47 \\
\hline Sausage & 53 & 51 & $0-36.38$ & 11.33 & 1.22 & 13.82 \\
\hline Dried processed meats & 18 & 15 & $0-2.68$ & 1.15 & 0.02 & 0.02 \\
\hline Ground meat products & 23 & 23 & $0.15-45.42$ & 7.12 & 0.57 & 4.06 \\
\hline Other Processed meats ${ }^{2)}$ & 9 & 9 & $0.22-1.79$ & 0.94 & 0.66 & 0.08 \\
\hline Salted fermented marine foods ${ }^{3)}$ & 9 & 9 & $0.15-19.14$ & 2.94 & 0.35 & 1.15 \\
\hline Daily intake of nitrite & - & - & - & - & - & $\begin{array}{r}48.06 \\
(0.87 \mu \mathrm{\mu g} / \mathrm{kg} \\
\text { weight/day) }\end{array}$ \\
\hline$\% \mathrm{ADI}^{4)}$ & - & - & - & - & - & 1.25 \\
\hline
\end{tabular}

${ }^{11} 0$ means the detection limit is below $0.1 \mu \mathrm{g} / \mathrm{g}$.

${ }^{2)}$ Other processed meats: Marinated meats, Rib products etc.

${ }^{3)}$ Sodium nitrite is only allowed in Cod egg products, cured salmon egg, and cured pollack among all of the salted fermented marine products.

${ }^{4)}$ Acceptable daily intake (ADI) of nitrate = estimated daily intake (EDI, $\mu \mathrm{g} / \mathrm{kg}$ weight/day) / ADI (70 $\mu \mathrm{g} / \mathrm{kg}$ weight/day) × 100; Adapted from Lee et al. [26].

Korea was 3.6\% that in Britain and Finland and 14.7\% that in Japan [26].

Crowe et al. [4] reported that the mean residual nitrite content in all bacon samples was 10.80 $\mathrm{mg} / \mathrm{kg}$; however, the middle cut bacon had significantly higher $(26.00 \mathrm{mg} / \mathrm{kg})$ residual nitrite content than back bacon $(8.87 \mathrm{mg} / \mathrm{kg} ; p=0.027)$ and medallion bacon $(4.47 \mathrm{mg} / \mathrm{kg} ; p=0.008)$. They concluded that there is a large variation in the mean residual nitrite content of the bacon sold in the United Kingdom and that all the reported values are within current regulatory limits. Our previous survey [10] found that the sodium nitrite content was low in commercial processed meat products, confirming that these products are safe for consumption. Oh et al. [30] also found that the sodium nitrite content continuously decreased via the processing, distribution, and storage of processed meat products. 


\section{Food additive}

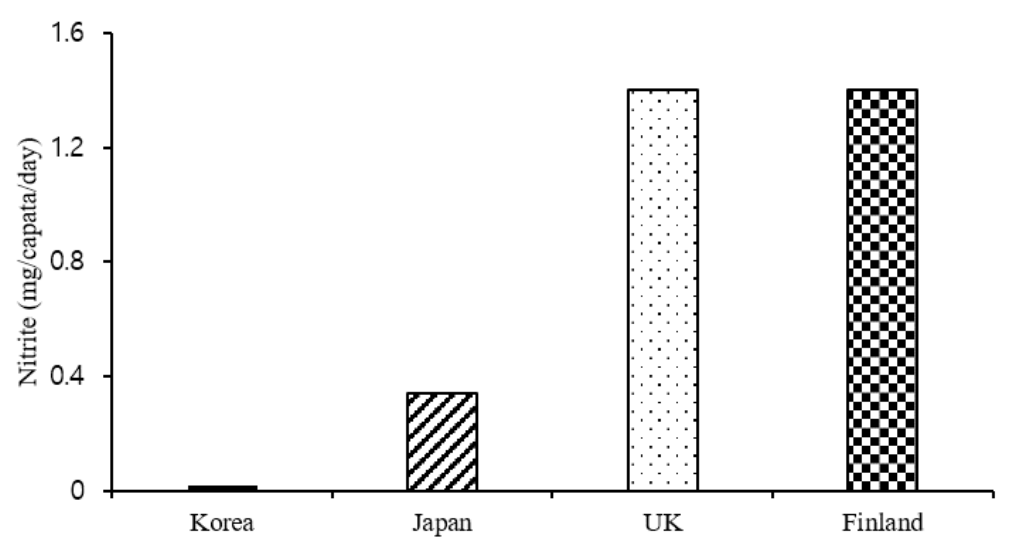

Fig. 5. Estimated intake of nitrites in countries, including Korea. Adapted and modified from Lee et al. with permission of Elsevier [26].

\section{INTAKE OF SODIUM NITRATES AND NITRITES THROUGH OTHER FACTORS}

Bryan et al. [47] reported that the concentrations of nitrite ions and nitroso compounds in tissues are affected by nitrite ingested from food. Although several epidemiological studies, including WHO/IARC, have reported that intake of meat products is related to cancer, nitrates and nitrites that enter our bodies are not only ingested through meat products but also through vegetables, grains, milk powder, salted fish, and beer [48,49]. When the previous studies were summarized, the variation of nitrates and nitrites in natural foods was large depending on the region where vegetables and fruits were grown; high concentrations of nitrite and nitrate were found in various natural foods (Table 4). The sodium nitrate content in the body ingested through vegetable intake amounts to more than $80 \%-90 \%$ of the total intake [15,50-52].

Meanwhile, nitrites are mostly produced and ingested through reactions with saliva during mastication, and very small amounts are ingested by processed meat [15]. This is because commensal bacteria in the oral cavity cause a reduction reaction that converts nitrate in saliva to nitrite. Most of the nitrates ingested by vegetables are also reduced to nitrites by bacteria in saliva, increasing the exposure concentration of nitrites in the human body [45,58]. For this reason, nitrites ingested by meat products account for less than about $5 \%$ of total intake [15]. According to Gangolli et al. [59], vegetables account for more than $85 \%$ of daily nitrate intake, and Hord et al. [46] estimated that dietary nitrates from vegetable intake would be approximately $80 \%$. For this reason, sodium nitrate and nitrite in the human body are the most frequently detected in saliva and are reported to have more intake through other foods than through processed meats. A comparison of nitrates and nitrite content in vegetables grown in Korea and other countries revealed higher nitrates in spinach and leek than in other vegetables, as well as in cabbage, radish, and lettuce [60]. Nitric oxide is also produced during the reduction of ingested nitrates, but an average of $1 \mathrm{mg} / \mathrm{kg}$ is synthesized within the body, and it is attracting renewed attention as a variety of useful ingredients in the body, including neurotransmitters, vascular expansion, and immunity. In addition, nitrates ingested through meals have important significance as a fundamental component of NO, and it has been reported that foliage such as cabbage and root vegetables such as radish contain a large amount of nitrates. van den Brand et al. [61] studied the dietary exposure assessment of nitrate 


\begin{tabular}{|c|c|c|}
\hline Foods & Nitrite (mg/kg) & Nitrate $(\mathrm{mg} / \mathrm{kg})$ \\
\hline Vegetables & $0.17-5.4$ & $436-1,980$ \\
\hline Cabbage & $0.17-11.7$ & $82.2-480$ \\
\hline Carrot & $4.3-12.6$ & $2,422.4-2,610$ \\
\hline Celery & 61.7 & $1,754.90$ \\
\hline Chicory & $0.18-9.03$ & $32-877$ \\
\hline Cucumber & $2.3-7.2$ & $347-1,100$ \\
\hline Egg plant & $2.1-4.5$ & $35.7-650$ \\
\hline Garlic & 1.1 & 382 \\
\hline Green onion & $0.28-16$ & $962-1,725$ \\
\hline Lettuce & $1.9-4.9$ & $36-609$ \\
\hline Onion & $3.6-138.4$ & $1,710-2,336.4$ \\
\hline Parsley & $0.5-5.6$ & $54-376$ \\
\hline Potato & 15.7 & 357.7 \\
\hline Pumpkin & 3.9 & 71.3 \\
\hline Sweet potato & $0.82-5.5$ & $6.4-175$ \\
\hline Tomato & $0.17-5.4$ & $436-1,980$ \\
\hline \multicolumn{3}{|l|}{ Fruits } \\
\hline Apple & 5.1 & 103 \\
\hline Banana & 52 & 444 \\
\hline Cherries & 4.2 & 212 \\
\hline Grapes & 7.1 & 160 \\
\hline Kiwi & 5.5 & 96.5 \\
\hline Melon & $4.2-7.65$ & $33.64-223$ \\
\hline Orange & 4.5 & 132 \\
\hline Pears & 4.3 & 173 \\
\hline Tangerine & 5.3 & 326 \\
\hline Watermelon & $4.8-5.5$ & $26.61-110$ \\
\hline
\end{tabular}

Adapted and modified from Suh et al. [53]; Raczuk et al. [54]; Rezaei et al. [55]; Bahadoran et al. [56]; Kmecl et al. [57].

and nitrite from all sources and reported that the vegetables contributed the most to the combined exposure in food in all scenarios, varying from 34\%-41\%. Food additive use contributed 8\%-9\% to the exposure, and drinking water contributed 3\%-19\%. In October 2015, the IARC of WHO reported that meat consumption caused colorectal cancer in humans. In a case-control study [62], the highest quartile of dietary nitrite intake was associated with an increased risk of colon cancer. Knekt et al. [63] found that the incidence of colorectal cancer $(73$ cases) was not associated with increasing quartiles of dietary nitrite intake. Dietary nitrate intake was not associated with the risk of colorectal cancer in the cohort study, and a higher dietary intake of nitrate was associated with a decreased risk of colon cancer in the Iowa case-control study [44]. It is well known that sodium nitrate can be converted to nitrite by the action of oral bacteria through the nitrosation process in the stomach. Indeed, nitrate and nitrite are interconverted via the bacterial reduction of nitrates in the mouth and gut and oxidation of nitrites in the blood. Nitrite is also partially converted to NO, which participates in gastric function [45]. If nitrite intake is a major cause of colorectal cancer, it is not accurate to conclude that the main source of nitrite intake in the body is through processed meat. This needs to be further studied through extensive epidemiological investigations. 


\section{PHYSIOLOGICAL ACTION OF NITRIC OXIDE IN THE BODY}

In order to enhance the understanding of the new biochemical role of NO ions, the fundamental role and pathways of nitrite ions for $\mathrm{NO}$ generation should be understood and how they affect health and disease [17]. It was discovered in the 1980s that NO is biosynthetic in mammals, which affects the immune system, cardiovascular, and nervous systems [17]. The first discovered endogenous NO production system was the L-arginine-NO synthase pathway, but it was later discovered that the Nitrate-nitrite-NO pathway also performs NO production. The Nitratenitrite-NO pathway indicates that NO can be produced from inorganic nitrates and nitrites [6467].

In fact, nitrite ions are the main factor in maintaining $\mathrm{NO}$ constancy in the body [68]. In the early 1980s, it was confirmed that nitrite ions were produced on their own in the body other than food intake [6,69], and then NO synthase system was discovered. In addition, NO was found to be the main factor in the production of nitrite ions in the body [70], as NO rapidly oxidizes to produce nitrite ions in the body [71] (Fig. 6).

Nitrate can be reduced to nitrite $\left(\mathrm{NO}_{2}^{-}\right)$by bacteria in the oral cavity and by xanthine oxidase and other enzymes in the tissues. The reduction of nitrate due to reduction is facilitated by a variety of enzymatic and non-enzymatic pathways. $\mathrm{NO}_{2}{ }^{-}$also produces $\mathrm{NO}$ and bioactive $\mathrm{NO}$ in the blood

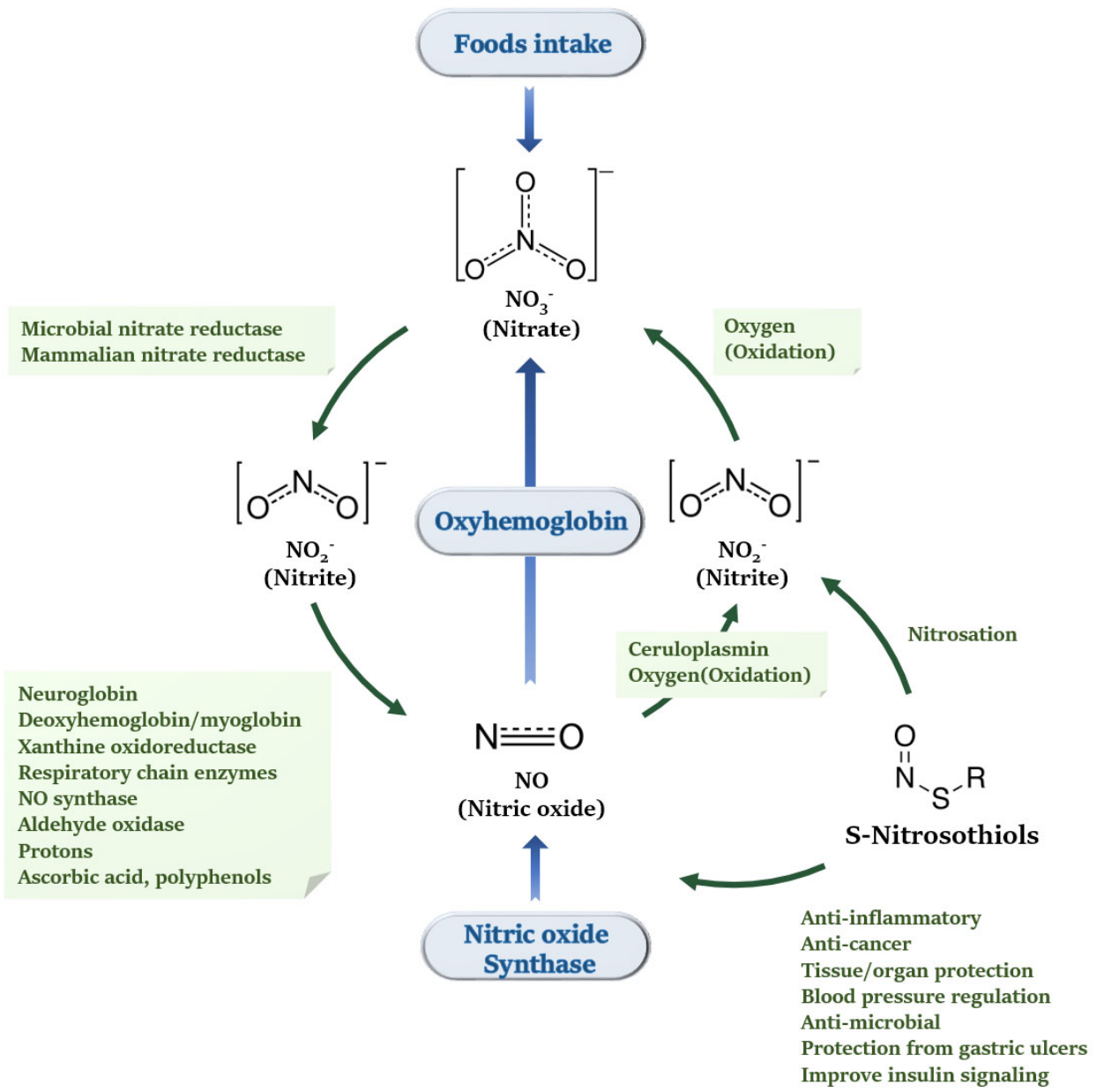

Fig. 6. Changes in nitric oxide in the body. 
and tissues. The reduction of nitrate and nitrite to NO is called the nitrogen oxide cycle $[72,73]$ (Fig. 6).

Nitrate itself is almost non-toxic, but nitrite reduced by oral fermentation bacteria or residual nitrite contained in food and pesticide residues can react with secondary amines to produce nitrosamine that could be causes cancer in the stomach and lungs $[15,16,74]$. $\mathrm{N}$-nitrosodimethylamine (NDMA), one of the most frequently occurring nitrosamines in food, is a potent carcinogen capable of causing malignant tumors in animal tissues such as the esophagus, liver, lung and stomach, this carcinogenicity was confirmed in studies using laboratory animals $[75,76]$. Nitrite ingested at a high concentration combines with hemoglobin in the blood to oxidize iron to iron (ш) to form methemoglobin $[74,77,78]$. As a result, the oxygen-carrying capacity of hemoglobin is reduced, which may cause cyanosis (methemoglobinemia) or anemic hypoxia. Acute sodium nitrite poisoning can also exacerbate high blood pressure and ischemic heart disease, leading to death [78]. In infants, the cyanotic response to nitrite may be more severe because the enzyme system reduced forms of nicotinamide adenine dinucleotide (NADH) cytochrome b5 reductase (NADH-methemoglobin reductase) does not exist sufficiently to protect against nitrite toxicity [79].

On the other hand, NO produced by the reduction of nitrates and nitrites, is a very important signaling substance in the body and plays various roles in virtually every organ in the body $[80,81]$. It is one of the most important neurotransmitters because NO is gas; therefore, it is not stored in synaptic vesicles, but synthesized according to the requirements, with rapid diffusion to neighboring neurons [82]. Nitric oxide affects all organ activities in the body, and abnormalities in the production and signal transmission of $\mathrm{NO}$ in the body are accompanied by various symptoms and diseases [83]. Therefore, maintaining the constancy of NO is important for health and disease prevention [17]. Naseem [84] suggested that the increase in the incidence and death of cardiovascular diseases is related to a decrease in the production of NO. Therefore, the consequences of NO deficiency vary and are serious [17]. Several studies $[72,85,86]$ have also suggested that some diseases can be suppressed by NO and nitrite ions ingested from food. When nitrite ions are produced and circulated in the body, they can be absorbed from peripheral tissues and stored in cells [52]. Nitric oxide also participates in food intake regulation [82]. Repeated administration of substances that inhibit the production of NO decreases appetite and body weight in obese animals [82].

In general, heme protein is required for the activation and metabolism of nitrite ions in human metabolism [87]. Many studies have shown that nitrite ions are physiologically recirculated in blood and tissues through the process of reduction or oxidation under the influence of hemoglobin and myoglobin, producing various nitrogen oxides [46,88-91]. Nitrite ions can be reduced in the body to produce $\mathrm{NO}$ or maintain nitrosothiols to maintain the constancy of $\mathrm{NO}$ [92] and, nitrite ions are the main factors that maintain $\mathrm{NO}$ constancy in the body [17].

There is now strong evidence supporting the notion that the most abundant products of $\mathrm{NO}$ oxidation (nitrite and nitrate) may be recycled back to bioactive $\mathrm{NO}$ and contribute to maintaining cardiovascular homeostasis [93]. Nitric oxide produced from nitrite ions or NO in the body as a diet also reduces cardiovascular disease in patients over the age of 40 and has reduced the incidence of blood pressure and inflammation [94]. The nitrite ion concentration in plasma decreases with an increase in cardiovascular disease [95]. In addition, studies by primates have shown that long-term nitrite ion supplies have shown beneficial effects on vascular contraction in the cerebrum [96]. Basal release of NO from L-arginine plays an important role in the regulation of blood flow and blood pressure [82]. Nitric oxide is slowly, but continually released in the arterial part of the cardiovascular system, and also regulates the tonus of small arteries and venules within the microcirculation 
$[82,97]$.

In human bodies, nitric acid ions are returned to nitrite ions, which are controlled by symbiotic bacteria. In the blood or tissue, nitrite ions are reduced to $\mathrm{NO}$ or become nitrogen oxides with other physiological functions. There are several enzymatic or non-enzymatic systems that catalyze this reduction process, most of which occur better under hypoxic conditions. The nitrogen-cycling system in mammals may become richer by ingesting foods rich in nitrite or nitric acid ions [98].

Several studies have focused on the function of nitric acid ions in in vivo ischemia or the lack of oxygen in the blood $[90,99,100]$. In mammalian tissues, the return of nitrite ions is affected by the electronic transmission systems [101,102], quantification [90,103], deoxyhemoglobin [104], and xanthine oxidase $[105,106]$. In addition, nitrosothiols can be produced under normal conditions and a lack of oxygen in the blood. The concentrations of nitrite ions and nitroso compounds in tissues were found to be affected by nitrites ingested from food [47]. In addition, a large amount of nitrite intake has significantly reduced damage caused by myocardial infarction [107], and it has been confirmed that the supply of nitrite ions through intravenous injections prior to re-contamination in the liver and myocardium can prevent damage caused by re-conduction [108]. Moreover, the supply of nitrite ions through local injection has improved the incidence of skin infections and ulcers [109].

Nitrogen monoxide produced from nitrite ions in meat processing products combined with heme protein prevented iron ions, which catalyze the oxidation of fat, from being disassembled from heme protein, showing the effect of inhibiting fatty oxidation. The nitrite ion also inhibited the change in low-density lipids by myeloperoxidase. Moreover, nitrogen monoxide produced from nitrite ions in the stomach has a significant effect on host defense mechanisms [110], and is adjusted to keep the mucous membrane in the stomach intact [102,111]. Nitrite ions prevent inflammation of capillaries and abnormalities in epithelial cells caused by dietary high fat or high cholesterol, and reduce C-reactive proteins (C-reactive proteins) that catalyze inflammatory reactions due to infection or trauma $[112,113]$. Long-term nitrite treatments have resulted in increased neoplasm and vascular enlargement caused by ischemia, and nitrite treatment has recently been used as a treatment for peripheral arteriosclerosis and arm and leg ischemia [114].

Nitric oxide plays a vital role in the reproductive system by regulating the hypothalamicpituitary-gonadal (HPG) axis [67]. Nitric oxide stimulates gonadotropin-releasing hormone secretion from the hypothalamus and has variable effects on luteinizing hormone release from the pituitary [67]. NO has also been reported to regulate testosterone production, penile erection, and sperm motility. Constantin et al. [115] reported that a mechanism whereby NO facilitates phosphatidylinositol 4,5-bisphosphate resynthesis and gonadotropin-releasing hormone neuron recovery from kisspeptin activation. They suggested that defining the overlap in kisspeptin and NO signaling pathways may provide an avenue for fertility treatment.

Indeed, NO exhibits strong inhibitory effects on the coagulation of blood and aggregation of platelets, thereby improving the flow and fluidity of blood [116]. The results of these studies indicate that nitrite ions can also be used as markers of $\mathrm{NO}$ activity in the body and in the diagnosis and treatment of diseases [117]. Moreover, the concentration of nitrite ions in the blood and tissues in the normal state of the body is affected by the intake of these ions from external sources. Thus, the dietary regulation of nitrous acid ions or nitrite ions can prevent many diseases that may arise from a lack of NO in the body [100] and it is not desirable to inhibit the intake of all sources of sodium nitrite through foods. 


\section{HEALTH BENEFITS OF MEAT CONSUMPTION}

Globally, meat intake accounts for approximately $8 \%$ of total energy intake, $18 \%$ of protein intake, and 23\% of fat intake [118]. Meat and meat products should be included in our diet as they are highly integrated in terms of nutrition and are important sources of numerous nutrients. In addition, meat protein is an important source of nutrients for humans because it has superior amino acid content, including all the essential amino acids, compared to other foods [119]. Due to the lack of lysine and low methionine content in soybeans [120] and all our major grains, such as rice and wheat, protein intake through meat is necessary to evenly consume all the essential amino acids. In the meantime, $\mathrm{WHO}$ and other international organizations have reported via their meal guidelines over the past few decades that saturated fatty acids in meat and meat products can lead to cardiovascular diseases, resulting in a significant decrease in the fat intake from animal foods, such as meat [121]. However, the ingestion of proper fat is essential for maintaining a healthy body. Linoleic acid, linolenic acid, arachidonic acid, and other essential fatty acids that are not synthesized in the human body must be taken from foods, such as meat. Among them, arachidonic acid, a precursor of prostaglandins which is involved in muscle contraction and relaxation, decrease in blood pressure, and anticancer action, is abundant in pork. Essential cholesterol is a component of the animal cell membranes [122] and it is essential for the production of sex hormones, bile acid, and vitamin $\mathrm{D}$ in the body. Meat is an excellent source of several vitamins and minerals. Meat contains a wide range of vitamin $B$ groups, such as thiamine, niacin, riboflavin, pantothenic acid, vitamin B6, and vitamin B12. Vitamin B plays important roles in the neurological behavior and energy metabolism of the food in the body [123]. According to a report by the United States Department of Agriculture (USDA) [124], red meat is known to supply approximately 25\% of the recommended intake of riboflavin, niacin, vitamin B6, and pantothenic acid per $100 \mathrm{~g}$ of red meat, especially $2 / 3 \mathrm{rd}$ of the recommended daily intake of vitamin B12 [119]. Among poultry, chicken breasts are a good source of niacin and they can meet $56 \%$ of the daily recommended intake for 100 $\mathrm{g}$ of red meat and $27 \%$ of the daily recommended intake for vitamin B6. Vitamin D, a lipid-soluble vitamin in meat, also plays important roles in calcium metabolism and bone formation and also regulates cell differentiation [118].

Meat and meat products play a critical role in the health of the human body and are important for achieving a healthy balanced diet, as they provide up to $18 \%$ of the recommended daily intake of iron [125]. Therefore, meat and meat products play an important role in preventing iron deficiency in the body [126]. Iron deficiency leads to many biological dysfunctions as well as child growth and development disorders $[127,128]$. In particular, iron deficiency anemia mostly occurs in children and childbearing women [118], and iron deficiency diseases have been reported even in developed countries. Iron is present in a variety of foods and exists in two major forms: heme iron and nonheme iron. Heme iron, in the form of iron bound to myoglobin and hemoglobin, exists only in animal foods, such as meat and meat products. On the other hand, non-heme iron is found mainly in food products, such as soybeans and vegetables $[118,129]$. Meat is the best source of heme iron [129] and heme iron from animal food is highly bioavailable and easily absorbed in the intestines, whereas non-heme iron has a low bioavailability of $2 \%-20 \%$ and is not easily absorbed by the body [129]. The iron content differs in each breed of meat with the largest amount of heme iron reported in beef, a medium amount in pork, and a relatively low content in white meat, such as chicken [130]. It is reported that $100 \mathrm{~g}$ of beef contains approximately $37 \%$ of the daily recommended amount of selenium, $26 \%$ zinc, and $20 \%$ potassium [124]. The zinc contained in meat is an essential nutrient for maintaining a healthy immune system, healing wounds, and boosting the growth of the children and reproduction. 
Red meat contains both selenium and potassium. Selenium acts as an antioxidant and is an essential mineral for the immune system functions, whereas potassium plays an important role in controlling the blood pressure [123]. The guidelines given by the World Cancer Research Fund (WCRF) / American Institute for Cancer Research (AICR) [118] recommend that the intake of red meat should not exceed $300 \mathrm{~g}$ per week (43 $\mathrm{g}$ per day) for the total population and $500 \mathrm{~g}$ per week (71 g per day) for individuals and that a very little amount of meat products should be consumed [118]. According to the Korean Nutrition Society [131], $60 \mathrm{~g}$ of meat per day is the recommended intake for adults. However, except for the people in the 19-29 age group, others with lower income amounts eat less than $60 \mathrm{~g}$ of meat per day. In the current study, Dobersek et al. [132] reported that those who avoided meat consumption exhibited a significantly higher risk of depression, anxiety, and/or self-harm behaviors. Thus, their study did not support meat avoidance as a strategy for improving the psychological health of the people. It is clear that proper meat consumption is beneficial to human health; however, excessive meat consumption and meat avoidance are not recommended.

\section{CONCLUSION}

This study investigated the effects of dietary sodium nitrite and meat on human health. Our previous study found that, although Korea had the highest incidence of colorectal cancer worldwide, the sodium nitrite intake in the country was three times lower than that in the United Kingdom, Finland, and Japan. Moreover, the consumption of processed meat in Korea is also much lower than that in the EU or North American countries. Sodium nitrite has recently become one of the most controversial substances regarding its effect on the risk of colorectal cancer. Most of the sodium nitrate (approximately 70\%-80\%) is consumed through vegetables and approximately $5 \%-20 \%$ of the consumed sodium nitrate is then converted to nitrites by enterobacteria present in the body. Therefore, meat or processed meat (in terms of sodium nitrite intake) might not be the main causative factor of colorectal cancer or other diseases. Hence, we should understand that having a balanced diet, which includes meat, is the most important factor for maintaining good health rather than excessive suppression of meat intake to prevent colorectal cancer or other diseases. Furthermore, there is a need to analyze the risk factors of different diseases by studying the effects of a variety of dietary factors on human health, instead of focusing only on a single dietary factor.

\section{REFERENCES}

1. Turesky RJ. Mechanistic evidence for red meat and processed meat intake and cancer risk: a follow-up on the international agency for research on cancer evaluation of 2015. CHIMIA Int J Chem. 2018;72:718-24. https://doi.org/10.2533/chimia.2018.718

2. Aykan NF. Red meat and colorectal cancer. Oncol Rev. 2015;9:288. https://doi.org/10.4081/ oncol.2015.288

3. Cantwell M, Elliott C. Nitrates, nitrites and nitrosamines from processed meat intake and colorectal cancer risk. J Clin Nutr Diet. 2017;3:27. https://doi.org/10.4172/24721921.100062

4. Crowe W, Elliott CT, Green BD. A review of the in vivo evidence investigating the role of nitrite exposure from processed meat consumption in the development of colorectal cancer. Nutrients. 2019;11:2673. https://doi.org/10.3390/nu11112673

5. DellaValle CT, Xiao Q, Yang G, Shu XO, Aschebrook-Kilfoy B, Zheng W, et al. Dietary nitrate and nitrite intake and risk of colorectal cancer in the Shanghai Women's Health Study. 
Int J Cancer. 2014;134:2917-26. https://doi.org/10.1002/ijc.28612

6. Karwowska M, Kononiuk A. Nitrates/nitrites in food—risk for nitrosative stress and benefits. Antioxidants. 2020;9:241. https://doi.org/10.3390/antiox9030241

7. EFSA [European Food Safety Authority]. Nitrate in vegetables - scientific opinion of the panel on contaminants in the food chain. EFSA J. 2008;6:689. https://doi.org/10.2903/j.efsa.2008.689

8. Luciano FB. The impacts of lean red meat consumption on human health: a review. CYTA J Food. 2009;7:143-51. https://doi.org/10.1080/19476330902940523

9. Yang SY, Kim YS, Lee JE, Seol J, Song JH, Chung GE, et al. Dietary protein and fat intake in relation to risk of colorectal adenoma in Korean. Medicine. 2016;95:e5453. https://doi. org/10.1097/MD.0000000000005453

10. Hur SJ, Yoon Y, Jo C, Jeong JY, Lee KT. Effect of dietary red meat on colorectal cancer risk-a review. Compr Rev Food Sci Food Saf. 2019;18:1812-24. https://doi. org/10.1111/1541-4337.12501

11. Mller AJ, Call JE, Whiting RC. Comparison of organic acid salts for Clostridium botulinum control in an uncured turkey product. J Food Prot. 1993;56:958-62. https://doi. org/10.4315/0362-028X-56.11.958

12. Pegg RB, Shahidi F. Nitrite curing of meat: the $\mathrm{N}$-nitrosamine problem and nitrite alternatives. Trumbull, Connecticut: Food \& Nutrition Press; 2000.

13. Cornforth DP, Jayasingh P. Chemical and physical characteristics of meat: colour and pigment. In: Jensen WK, Devine C, Dikeman, editors. Encyclopedia of meat sciences. Oxford: Elsevier Science; 2004. p. 249-56.

14. Sindelar JJ, Houser TA. Alternative curing system. In: Tarté R, editor. Ingredients in meat products: properties, functionality and applications. New York, NY: Springer; 2009. p. 379405.

15. Sindelar JJ, Milkowski AL. Human safety controversies surrounding nitrate and nitrite in the diet. Nitric Oxide. 2012;26:259-66. https://doi.org/10.1016/j.niox.2012.03.011

16. Govari M, Pexara A. Nitrates and nitrites in meat products. J Hell Vet Med Soc. 2015;66: 127-40. https://doi.org/10.12681/jhvms.15856

17. Hur SJ, Jang A, Jeong JY, Jo C, Chin KB, Lee KT. Misunderstanding and truths for controversy of carcinogenic substances in meat products. Food Sci Anim Resour. 2015;4:7-22.

18. Sebranek JG, Bacus JN. Cured meat products without direct addition of nitrate or nitrite: what are the issues?. Meat Sci. 2007;77:136-47.https://doi.org/10.1016/j.meatsci.2007.03.025

19. Keeton JT, Osburn WN, Hardin MD, Bryan NS. A national survey of the nitrite/nitrate concentrations in cured meat products and non-meat foods available at retail [Internet]. Porkcheckoff. 2009 [cited 2021 Jun 23]. https://www.porkcdn.com/sites/research/ResearchDocuments/08-124-KEETON-TxA-M.pdf

20. National Toxicology Program. Toxicology and carcinogenesis studies of sodium nitrite (CAS NO. 7632-00-0) in F344/N rats and B6C3F1 mice (drinking water studies). Natl Toxicol Program Tech Rep Ser. 2001;495:7-273.

21. Bharucha KR, Cross CK, Rubin LJ. Mechanism of N-nitrosopyrrolidine formation in bacon. J Agric Food Chem. 1979;27:63-9. https://doi.org/10.1021/jf60221a035

22. Kim $\mathrm{GH}$, Chin KB. Evaluation of quality characteristics of low-nitrite pork sausages with paprika oleoresin solution during refrigerated storage. Food Sci Anim Resour. 2021;41:42839. https://doi.org/10.5851/kosfa.2021.e8

23. Krause BL. Incubation of curing brines for the production of ready-to-eat uncured ham [Master's thesis]. Ames, IA: Iowa State University; 2009. 
24. Sullivan GA. Naturally cured meats: quality, safety, and chemistry [Ph.D. dissertation]. Ames, IA: Iowa State University; 2011.

25. Sindelar J, Milkowski A. Sodium nitrite in processed meat and poultry meats: a review of curing and examining the risk/benefit of its use. Am Meat Sci Assoc White Pap Ser. 2011;3:1-14.

26. Lee $\mathrm{CH}, \mathrm{Cho} \mathrm{YH}$, Park $\mathrm{KH}$. Assessment of estimated daily intake of nitrite by average consumption of processed foods in Korea. Food Control. 2006;17:950-6. https://doi.org/ 10.1016/j.foodcont.2005.07.001

27. JECFA [The Joint FAO/WHO Expert Committee on Food Additives]. Evaluations of the Joint FAO/WHO Expert Committee on Food Additives: nitrite [Internet]. World Health Organization. 2002 [cited 2021 Sep 16]. https://apps.who.int/food-additives-contaminants-jecfa-database/chemical.aspx?chemID $=711$

28. Choi SH, Lee MS, Kim EY, Kim WS, Lee JY, Kim WS. Dietary intake of food additive by Korean population - sulfur dioxide, nitrite. Cheongju: Korean Health Industry Development Institute (KHIDI); 2009. Report No.: TRKO201100007913.

29. Bryant C, Sanctorum H. Alternative proteins, evolving attitudes: comparing consumer attitudes to plant-based and cultured meat in Belgium in two consecutive years. Appetite. 2021;161:105161. https://doi.org/10.1016/j.appet.2021.105161

30. Oh MH, Yoon Y, Kim HY, Kim CJ. Development of microbial predictive growth models and establishment of safety guideline on low sodium meat products. Jeonju: Rural Development Administration; 2015. Report No.: TRKO201500010612.

31. U.S. Food and Drug Administration. CFR - Code of Federal Regulations Title 21 [Internet]. U.S. Food and Drug Administration. 2020 [cited 2021 July 23]. https://www.accessdata. fda.gov/scripts/cdrh/cfdocs/cfcfr/CFRSearch.cfm?fr=172.175

32. Codex Alimentarius. Discussion paper on the use of nitrates (ins 251,252) and nitrites (ins 249, 250) - CCFA 49 [Internet]. FAO,WHO. 2017 [cited 2021 July 23]. http://www.fao. org/fao-who-codexalimentarius/committees/ewg/detail/fr/c/878191/

33. Publications Office of the European Union. Commission regulation (EU) No 1129/2011 of 11 November 2011 amending Annex II to Regulation (EC) No 1333/2008 of the European Parliament and of the Council by establishing a union list of food additives (text with EEA relevance) [Internet]. Publications Office of the European Union. 2011 [cited 2021 July 23]. https://op.europa.eu/en/publication-detail/-/publication/28cb4a37-b40e-11e3-86f9-01aa75ed71a1/language-en

34. Ministry of Food and Drug Safety. Korea food additives code [Internet]. Ministry of Food and Drug Safety. 2011 [cited 2021 Jun 23]. https://www.foodsafetykorea.go.kr/foodcode/04_03.jsp?idx=820

35. Korea Food Safety Research Institute. Nitrite and food safety: 5th workshop report [Internet]. Korea Food Safety Research Institute. 2010 [cited 2021 July 24]. http://kfsri.or.kr/board/ view.asp?idx=24\&mode=read

36. Ham HJ, Yang YM, Yun E. Nitrite contents survey on ham, sausage and bacon in market. J Food Hyg Saf. 2003;18:33-5.

37. Cho YH, Lee JY, Kim DH. Daily dietary intake of food additive by Korean population-bleaching and color retention agent. Cheongju: Korea Food \& Drug Administration; 2005. Report No.: TRKO201000016228.

38. Kim YJ, Han HJ, Kim JE, Kim YS, Lee JH. A survey of nitrite content in meat products in Seoul (2012 2014). Rep Seoul Metrop Gov Res Inst Public Health Environ 2014;50:131-7.

39. Choi SH, Suh HJ. Determination and estimation of daily nitrite intake from processed meats in 
Korea.J Consum Prot Food Saf. 2017;12:15-22. https://doi.org/10.1007/s00003-016-1075-8

40. Lee HS. Exposure estimates of nitrite and nitrate from consumption of cured meat products by the U.S. population. Food Addit Contam Part A. 2018;35:29-39. https://doi.org/10.1080 /19440049.2017.1400696

41. Menard C, Heraud F, Volatier JL, Leblanc JC. Assessment of dietary exposure of nitrate and nitrite in France. Food Addit Contam Part A. 2008;25:971-88. https://doi. org/10.1080/02652030801946561

42. Hsu J, Arcot J, Lee NA. Nitrate and nitrite quantification from cured meat and vegetables and their estimated dietary intake in Australians. Food Chem. 2009;115:334-9. https://doi. org/10.1016/j.foodchem.2008.11.081

43. Della Betta F, Pereira LM, Siqueira MA, Valese AC, Daguer H, Fett R, et al. A sub-minute CZE method to determine nitrate and nitrite in meat products: an alternative for routine analysis. Meat Sci. 2016;119:62-8. https://doi.org/10.1016/j.meatsci.2016.04.011

44. Lee JS, Lee JH, Bang JH, Kim SH, Kim MJ, Lee JH, et al. Changes in nitrite content of meat products by cooking conditions. J Agric Life Environ Sci. 2015;27:49-52.

45. IARC [International Agency for Research on Cancer]. Ingested nitrate and nitrite, and cyanobacterial peptide toxins. IARC Monogr Eval Carcinog Risks Hum. 2010;94:448.

46. Hord NG, Tang Y, Bryan NS. Food sources of nitrates and nitrites: the physiologic context for potential health benefits. Am J Clin Nutr. 2009;90:1-10. https://doi.org/10.3945/ ajcn.2008.27131

47. Bryan NS, Fernandez BO, Bauer SM, Garcia-Saura MF, Milsom AB, Rassaf T, et al. Nitrite is a signaling molecule and regulator of gene expression in mammalian tissues. Nat Chem Biol. 2005;1:290-7. https://doi.org/10.1038/nchembio734

48. Hotchkiss JH, Cassens RG. Nitrate, nitrite, and nitroso compounds in foods. Food Technol (United States). 1987;41.

49. Ferysiuk K, Wójciak KM. Reduction of nitrite in meat products through the application of various plant-based ingredients. Antioxidants. 2020;9:711. https://doi.org/10.3390/antiox 9080711

50. Cassens RG. Residual nitrite in cured meat. Food Technol (Chicago). 1997;51:53-5.

51. Yong HI, Kim TK, Choi HD, Jang HW, Jung S, Choi YS. Clean label meat technology: pre-converted nitrite as a natural curing. Food Sci Anim Resour. 2021;41:173-84. https:// doi.org/10.5851/kosfa.2020.e96

52. $\mathrm{Ma} \mathrm{L}, \mathrm{Hu}$ HL, Feng X, Wang S. Nitrate and nitrite in health and disease. Aging Dis. 2018;9:938-45. https://doi.org/10.14336/AD.2017.1207

53. Suh J, Paek OJ, Kang Y, Ahn JE, Jung JS, An YS, et al. Risk assessment on nitrate and nitrite in vegetables available in Korean diet. J Appl Biol Chem. 2013;56:205-11. https://doi. org/10.3839/jabc.2013.033

54. Raczuk J, Wadas W, Głozak K. Nitrates and nitrites in selected vegetables purchased at supermarkets in Siedlce, Poland. Rocz Panstw Zakl Hig. 2014;65:15-20.

55. Rezaei M, Fani A, Moini AL, Mirzajani P, Malekirad AA, Rafiei M. Determining nitrate and nitrite content in beverages, fruits, vegetables, and stews marketed in Arak, Iran. Int Sch Res Notices. 2014;2014:439702. https://doi.org/10.1155/2014/439702

56. Bahadoran Z, Mirmiran P, Jeddi S, Azizi F, Ghasemi A, Hadaegh F. Nitrate and nitrite content of vegetables, fruits, grains, legumes, dairy products, meats and processed meats. J Food Compos Anal. 2016;51:93-105. https://doi.org/10.1016/j.jfca.2016.06.006

57. Kmecl V, Knap T, Žnidarčič D. Evaluation of the nitrate and nitrite content of vegetables commonly grown in Slovenia. Ital J Agron. 2017;12. https://doi.org/10.4081/ija.2017.801 
58. Bryan NS, Alexander DD, Coughlin JR, Milkowski AL, Boffetta P. Ingested nitrate and nitrite and stomach cancer risk: an updated review. Food Chem Toxicol. 2012;50:3646-65. https://doi.org/10.1016/j.fct.2012.07.062

59. Gangolli SD, van den Brandt PA, Feron VJ, Janzowsky C, Koeman JH, Speijers GJA, et al. Nitrate, nitrite and N-nitroso compounds. Eur J Pharmacol Environ Toxicol Pharmacol. 1994;292:1-38. https://doi.org/10.1016/0926-6917(94)90022-1

60. Chung SY, Kim JS, Kim M, Hong MK, Lee JO, Kim CM, et al. Survey of nitrate and nitrite contents of vegetables grown in Korea. Food Addit Contam Part A. 2003;20:621-8. https:// doi.org/10.1080/0265203031000124146

61. van den Brand AD, Beukers M, Niekerk M, van Donkersgoed G, van der Aa M, van de Ven $\mathrm{B}$, et al. Assessment of the combined nitrate and nitrite exposure from food and drinking water: application of uncertainty around the nitrate to nitrite conversion factor. Food Addit Contam Part A. 2020;37:568-82. https://doi.org/10.1080/19440049.2019.1707294

62. De Roos AJ, Ward MH, Lynch CF, Cantor KP. Nitrate in public water supplies and the risk of colon and rectum cancers. Epidemiology. 2003;14:640-9. https://doi.org/10.1097/01. ede.0000091605.01334.d3

63. Knekt P, Järvinen R, Dich J, Hakulinen T. Risk of colorectal and other gastro-intestinal cancers after exposure to nitrate, nitrite and N-nitroso compounds: a follow-up study. Int J Cancer. 1999;80:852-6. https://doi.org/10.1002/(SICI)1097-0215(19990315)80:6<852::AIDIJC9>3.0.CO;2-S

64. Lundberg JO, Weitzberg E. NO generation from inorganic nitrate and nitrite: role in physiology, nutrition and therapeutics. Arch Pharm Res. 2009;32:1119-26. https://doi. org/10.1007/s12272-009-1803-z

65. Weitzberg E, Lundberg JO. Dietary nitrate - a slow train coming. J Physiol. 2011;589:53334. https://doi.org/10.1113/jphysiol.2011.220673

66. Klinger JR, Kadowitz PJ. The NO pathway in pulmonary vascular disease. Am J Cardiol. 2017;120:S71-9. https://doi.org/10.1016/j.amjcard.2017.06.012

67. Oghbaei H, Hamidian G, Alipour MR, Alipour S, Keyhanmanesh R. The effect of prolonged dietary sodium nitrate treatment on the hypothalamus-pituitary-gonadal axis and testicular structure and function in streptozotocin-induced diabetic male rats. Food Funct. 2020;11:2451-65. https://doi.org/10.1039/C9FO00974D

68. Dejam A, Hunter CJ, Pelletier MM, Hsu LL, Machado RF, Shiva S, et al. Erythrocytes are the major intravascular storage sites of nitrite in human blood. Blood. 2005;106:734-9. https://doi.org/10.1182/blood-2005-02-0567

69. Green LC, Tannenbaum SR, Goldman P. Nitrate synthesis in the germfree and conventional rat. Science. 1981;212:56-8. https://doi.org/10.1126/science.6451927

70. Hibbs JB Jr., Taintor RR, Vavrin Z. Macrophage cytotoxicity: role for L-arginine deiminase and imino nitrogen oxidation to nitrite. Science. 1987;235:473-6. https://doi.org/10.1126/ science. 2432665

71. Villar ML, Godwin IR, Hegarty RS, Erler DV, Farid HT, Nolan JV. Nitrate and nitrite absorption, recycling and retention in tissues of sheep. Small Rumin Res. 2021;200:106392. https://doi.org/10.1016/j.smallrumres.2021.106392

72. Lundberg JO, Gladwin MT, Ahluwalia A, Benjamin N, Bryan NS, Butler A, et al. Nitrate and nitrite in biology, nutrition and therapeutics. Nat Chem Biol. 2009;5:865-9. https://doi. org/10.1038/nchembio.260

73. Bryan NS. Dietary nitrite: from menace to marvel. Funct Foods Health Dis. 2016;6:691701. https://doi.org/10.31989/ffhd.v6i11.295 
74. Chamandoost S, Fateh Moradi M, Hosseini M. A review of nitrate and nitrite toxicity in foods.J Hum Environ Health Promot. 2016;1:80-6. https://doi.org/10.29252/jhehp.1.2.80

75. Tricker AR, Preussmann R. Carcinogenic N-nitrosamines in the diet: occurrence, formation, mechanisms and carcinogenic potential. Mutat Res Genet Toxicol. 1991;259:277-89. https:// doi.org/10.1016/0165-1218(91)90123-4

76. Song P, Wu L, Guan W. Dietary nitrates, nitrites, and nitrosamines intake and the risk of gastric cancer: a meta-analysis. Nutrients. 2015;7:9872-95. https://doi.org/10.3390/ nu7125505

77. De Mey E, De Maere H, Paelinck H, Fraeye I. Volatile N-nitrosamines in meat products: potential precursors, influence of processing, and mitigation strategies. Crit Rev Food Sci Nutr. 2017;57:2909-23. https://doi.org/10.1080/10408398.2015.1078769

78. Cvetković D, Živković V, Lukić V, Nikolić S. Sodium nitrite food poisoning in one family. Forensic Sci Med Pathol. 2019;15:102-5. https://doi.org/10.1007/s12024-018-0036-1

79. L'hirondel JL. Are dietary nitrates a threat to human health. In: Morris J, Bates R, editors. Fearing food: risk, health and environment. Oxford: Butterworth-Henemann; 1999:38-46.

80. Esplugues JV. NO as a signalling molecule in the nervous system. Br J Pharmacol. 2002;135:1079-95. https://doi.org/10.1038/sj.bjp.0704569

81. Oliver S, Pham TTP, Li Y, Xu FJ, Boyer C. More than skin deep: using polymers to facilitate topical delivery of nitric oxide. Biomater Sci. 2021;9:391-405. https://doi.org/10.1039/ D0BM01197E

82. Antosova M, Plevkova J, Strapkova A, Buday T. Nitric oxide—important messenger in human body. Open J Mol Integr Physiol. 2012;2:98-106. https://doi.org/10.4236/ ojmip.2012.23014

83. Moncada S, Higgs EA. Endogenous nitric oxide: physiology, pathology and clinical relevance. Eur J Clin Invest. 1991;21:361-74. https://doi.org/10.1111/j.1365-2362.1991. tb01383.x

84. Naseem KM. The role of nitric oxide in cardiovascular diseases. Mol Aspects Med. 2005;26:33-65. https://doi.org/10.1016/j.mam.2004.09.003

85. Lundberg JO, Weitzberg E, Gladwin MT. The nitrate-nitrite-nitric oxide pathway in physiology and therapeutics. Nat Rev Drug Discov. 2008;7:156-67. https://doi.org/10.1038/ $\operatorname{nrd} 2466$

86. Bryan NS, Loscalzo J. Nitrite and nitrate in human health and disease.Totowa, NJ: Humana Press; 2017.

87. Gladwin MT, Crawford JH, Patel RP. The biochemistry of nitric oxide, nitrite, and hemoglobin: role in blood flow regulation. Free Radic Biol Med. 2004;36:707-17. https://doi. org/10.1016/j.freeradbiomed.2003.11.032

88. Benjamin N, O’Driscoll F, Dougall H, Duncan C, Smith L, Golden M, et al. Stomach NO synthesis. Nature. 1994;368:502. https://doi.org/10.1038/368502a0

89. Lundberg JO, Weitzberg E, Lundberg JM, Alving K. Intragastric nitric oxide production in humans: measurements in expelled air. Gut. 1994;35:1543-6.

90. Zweier JL, Wang P, Samouilov A, Kuppusamy P. Enzyme-independent formation of nitric oxide in biological tissues. Nat Med. 1995;1:804-9. https://doi.org/10.1038/nm0895-804

91. Pereira C, Ferreira NR, Rocha BS, Barbosa RM, Laranjinha J. The redox interplay between nitrite and nitric oxide: from the gut to the brain. Redox Biol. 2013;1:276-84. https://doi. org/10.1016/j.redox.2013.04.004

92. Cardenas AJP, Abelman R, Warren TH. Conversion of nitrite to nitric oxide at zinc via S-nitrosothiols. Chem Commun. 2014;50:168-70. https://doi.org/10.1039/C3CC46102E 
93. Sanches-Lopes JM, Ferreira GC, Pinheiro LC, Kemp R, Tanus-Santos JE. Consistent gastric $\mathrm{pH}$-dependent effects of suppressors of gastric acid secretion on the dresponses to oral nitrite. Biochem Pharmacol. 2020;177:113940. https://doi.org/10.1016/j.bcp.2020.113940

94. Zand J, Lanza F, Garg HK, Bryan NS. All-natural nitrite and nitrate containing dietary supplement promotes nitric oxide production and reduces triglycerides in humans. Nutr Res. 2011;31:262-9. https://doi.org/10.1016/j.nutres.2011.03.008

95. Kleinbongard P, Dejam A, Lauer T, Jax T, Kerber S, Gharini P, et al. Plasma nitrite concentrations reflect the degree of endothelial dysfunction in humans. Free Radic Biol Med. 2006;40:295-302. https://doi.org/10.1016/j.freeradbiomed.2005.08.025

96. Pluta RM, Dejam A, Grimes G, Gladwin MT, Oldfield EH. Nitrite infusions to prevent delayed cerebral vasospasm in a primate model of subarachnoid hemorrhage. JAMA. 2005;293:1477-84. https://doi.org/10.1001/jama.293.12.1477

97. Hollenberg NK. Organ systems dependent on nitric oxide and the potential for nitric oxide-targeted therapies in related diseases. J Clin Hypertens. 2006;8:63-76. https://doi. org/10.1111/j.1524-6175.2006.06042.x

98. Parthasarathy DK, Bryan NS. Sodium nitrite: the "cure" for nitric oxide insufficiency. Meat Sci. 2012;92:274-9. https://doi.org/10.1016/j.meatsci.2012.03.001

99. Bryan NS, Rassaf T, Maloney RE, Rodriguez CM, Saijo F, Rodriguez JR, et al. Cellular targets and mechanisms of nitros(yl)ation: an insight into their nature and kinetics in vivo. Proc Natl Acad Sci USA. 2004;101:4308-13. https://doi.org/10.1073/pnas.0306706101

100. Bryan NS. Nitrite in nitric oxide biology: cause or consequence?: a systems-based review. Free Radic Biol Med. 2006;41:691-701. https://doi.org/10.1016/j.freeradbiomed.2006.05.019

101. Kozlov AV, Staniek K, Nohl H. Nitrite reductase activity is a novel function of mammalian mitochondria. FEBS Lett. 1999;454:127-30. https://doi.org/10.1016/S00145793(99)00788-7

102. Gupta KJ, Igamberdiev AU. Reactive nitrogen species in mitochondria and their implications in plant energy status and hypoxic stress tolerance. Front Plant Sci. 2016;7:369. https:// doi.org/10.3389/fpls.2016.00369

103. Csonka C, Páli T, Bencsik P, Görbe A, Ferdinandy P, Csont T. Measurement of NO in biological samples. Br J Pharmacol. 2015;172:1620-32. https://doi.org/10.1111/bph.12832

104. Cosby K, Partovi KS, Crawford JH, Patel RP, Reiter CD, Martyr S, et al. Nitrite reduction to nitric oxide by deoxyhemoglobin vasodilates the human circulation. Nat Med. 2003;9:1498505. https://doi.org/10.1038/nm954

105. Li H, Samouilov A, Liu X, Zweier JL. Characterization of the effects of oxygen on xanthine oxidase-mediated nitric oxide formation. J Biol Chem. 2004;279:16939-46. https://doi. org/10.1074/jbc.M314336200

106. Webb A, Bond R, McLean P, Uppal R, Benjamin N, Ahluwalia A. Reduction of nitrite to nitric oxide during ischemia protects against myocardial ischemia-reperfusion damage. Proc Natl Acad Sci USA. 2004;101:13683-8. https://doi.org/10.1073/pnas.0402927101

107. Bryan NS, Calvert JW, Elrod JW, Gundewar S, Ji SY, Lefer DJ. Dietary nitrite supplementation protects against myocardial ischemia-reperfusion injury. Proc Natl Acad Sci USA. 2007;104:19144-9. https://doi.org/10.1073/pnas.0706579104

108. Duranski MR, Greer JJ, Dejam A, Jaganmohan S, Hogg N, Langston W, et al. Cytoprotective effects of nitrite during in vivo ischemia-reperfusion of the heart and liver. J Clin Invest. 2005;115:1232-40. https://doi.org/10.1172/JCI22493

109. Hardwick JBJ, Tucker AT, Wilks M, Johnston A, Benjamin N. A novel method for the delivery of nitric oxide therapy to the skin of human subjects using a semi-permeable membrane. 
Clin Sci (Lond). 2001;100:395-400.https://doi.org/10.1042/cs1000395

110. Petersson J. Nitrate, nitrite and nitric oxide in gastric mucosal defense [Ph.D. dissertation]. Uppsala, Sweden:Uppsala University; 2008.

111. Björne H, Petersson J, Phillipson M, Weitzberg E, Holm L, Lundberg JO. Nitrite in saliva increases gastric mucosal blood flow and mucus thickness. J Clin Invest. 2004;113:106-14. https://doi.org/10.1172/JCI19019

112. Stokes KY, Dugas TR, Tang Y, Garg H, Guidry E, Bryan NS. Dietary nitrite prevents hypercholesterolemic microvascular inflammation and reverses endothelial dysfunction. Am J Physiol Heart Circ Physiol. 2009;296:H1281-8. https://doi.org/10.1152/ ajpheart.01291.2008

113. Waltz P, Escobar D, Botero AM, Zuckerbraun BS. Nitrate/nitrite as critical mediators to limit oxidative injury and inflammation. Antioxid Redox Signal. 2015;23:328-39. https://doi. org/10.1089/ars.2015.6256

114. Kumar D, Branch BG, Pattillo CB, Hood J, Thoma S, Simpson S, et al. Chronic sodium nitrite therapy augments ischemia-induced angiogenesis and arteriogenesis. Proc Natl Acad Sci USA. 2008;105:7540-5. https://doi.org/10.1073/pnas.0711480105

115. Constantin S, Reynolds D, Oh A, Pizano K, Wray S. Nitric oxide resets kisspeptin-excited GnRH neurons via PIP2 replenishment. Proc Natl Acad Sci USA. 2021;118:e2012339118. https://doi.org/10.1073/pnas.2012339118

116. Park JW, Piknova B, Nghiem K, Lozier JN, Schechter AN. Inhibitory effect of nitrite on coagulation processes demonstrated by thrombelastography. Nitric Oxide. 2014;40:45-51. https://doi.org/10.1016/j.niox.2014.05.006

117. Kleinbongard P, Dejam A, Lauer T, Rassaf T, Schindler A, Picker O, et al. Plasma nitrite reflects constitutive nitric oxide synthase activity in mammals. Free Radic Biol Med. 2003;35:790-6. https://doi.org/10.1016/S0891-5849(03)00406-4

118. Marmot M, Atinmo T, Byers T, Chen J, Hirohata T, Jackson A, et al. Food, nutrition, physical activity and the prevention of cancer: a global perspective. Washington, D.C.: World Cancer Research Fund/American Institute for Cancer Research; 2007.

119. Williams P. Nutritional composition of red meat. Nutr Diet. 2007;64:S113-9. https://doi. org/10.1111/j.1747-0080.2007.00197.x

120. Elango R, Ball RO, Pencharz PB. Amino acid requirements in humans: with a special emphasis on the metabolic availability of amino acids. Amino Acids. 2009;37:19. https://doi. org/10.1007/s00726-009-0234-y

121. Krauss RM, Eckel RH, Howard B, Appel LJ, Daniels SR, Deckelbaum RJ, et al. AHA dietary guidelines: revision 2000: a statement for healthcare professionals from the Nutrition Committee of the American Heart Association. Circulation. 2000;102:2284-99. https://doi. org/10.1161/01.CIR.102.18.2284

122. Abbott SK, Else PL, Atkins TA, Hulbert AJ. Fatty acid composition of membrane bilayers: importance of diet polyunsaturated fat balance. Biochim Biophys Acta Biomembr. 2012;1818:1309-17. https://doi.org/10.1016/j.bbamem.2012.01.011

123. Binnie MA, Barlow K, Johnson V, Harrison C. Red meats: time for a paradigm shift in dietary advice. Meat Sci. 2014;98:445-51. https://doi.org/10.1016/j.meatsci.2014.06.024

124. USDA [United States Department of Agriculture]. Composition of foods raw, processed, prepared USDA National Nutrient Database for Standard Reference, Release 24. USDA; 2011.

125. Geissler C, Singh M. Iron, meat and health. Nutrients. 2011;3:283-316. https://doi. org/10.3390/nu3030283 
126. United Nations Children's Fund, United Nations University, World Health Organization. Iron deficiency anemia. Assessment, prevention, and control. A guide for programme managers. Geneva: World Health Organization; 2001. p. 47-62.

127. Grantham-McGregor S, Ani C. A review of studies on the effect of iron deficiency on cognitive development in children. J Nutr. 2001;131:649S-68S. https://doi.org/10.1093/ jn/131.2.649S

128. Lozoff B, Georgieff MK. Iron deficiency and brain development. Semin Pediatr Neurol. 2006;13:158-65. https://doi.org/10.1016/j.spen.2006.08.004

129. Turhan S, Altunkaynak TB, Yazici F. A note on the total and heme iron contents of readyto-eat doner kebabs. Meat Sci. 2004;67:191-4. https://doi.org/10.1016/j.meatsci.2003.10.004

130. Pereira PMCC, Vicente AFRB. Meat nutritional composition and nutritive role in the human diet. Meat Sci. 2013;93:586-92. https://doi.org/10.1016/j.meatsci.2012.09.018

131. Ministry of Health and Welfare, The Korean Nutrition Society. Dietary Reference Intakes for Koreans energy and macronutrients. Seoul: Ministry of Health and Welfare; 2020. Report No.: 11-1352000-002852-01

132. Dobersek U, Wy G, Adkins J, Altmeyer S, Krout K, Lavie CJ, et al. Meat and mental health: a systematic review of meat abstention and depression, anxiety, and related phenomena. Crit Rev Food Sci Nutr. 2021;61:622-35. https://doi.org/10.1080/10408398.2020.1741505 